Philosophical Inquiry in Education

\title{
The Legacy of Isocrates and a Platonic Alternative: History, Political Philosophy and the Value of Education (James R. Muir)
}

\section{Avi I. Mintz}

Volume 26, Number 1, 2019

URI: https://id.erudit.org/iderudit/1071423ar

DOI: https://doi.org/10.7202/1071423ar

See table of contents

Publisher(s)

Canadian Philosophy of Education Society

ISSN

2369-8659 (digital)

Explore this journal

\section{Cite this review}

Mintz, A. (2019). Review of [The Legacy of Isocrates and a Platonic Alternative: History, Political Philosophy and the Value of Education (James R. Muir)]. Philosophical Inquiry in Education, 26(1), 92-97.

https://doi.org/10.7202/1071423ar viewed online.

https://apropos.erudit.org/en/users/policy-on-use/ 
Review of

\section{The Legacy of Isocrates and a Platonic} Alternative: History, Political Philosophy and the Value of Education

by James R. Muir, New York and London: Routledge, 2019

AVI I. MINTZ

If asked to identify the roots of higher education, of "academia," most people would point to Plato's Academy in fourth century BCE Athens. But Plato was not alone in establishing a school there, and he was not the first. Earlier, Isocrates had opened a school which, like Plato's, became a hub of Athenian intellectual life, attracting students not only from Greece but from abroad as well. In addition to establishing two of the most famous schools of Classical Greece, Plato and Isocrates were similar in other ways; perhaps most importantly, they both identified themselves as philosophers. Each, however, created a distinct conception of philosophical education. For Plato, the purpose of education was to attain knowledge. That knowledge may very well have been useful, but its usefulness was secondary. Isocrates, in contrast, thought that the crown jewel of philosophical education was rhetoric, the study of which enables people to address the concerns of their community.

Isocrates, in a thinly veiled critique of Plato's Academy, offers damning praise: "those who teach astrology, geometry, and other branches of learning do not harm but rather benefit their students, less than they promise but more than others think" (Isocrates 2000, 15.261). Such teaching, Isocrates writes, is mere "'mental gymnastics' and 'a preparation for philosophy' - a more mature subject than what children learn in schools but for the most part similar" (Isocrates 2000, 266). Plato, for his part, has Socrates say of a young Isocrates in Phaedrus, "I wouldn't be at all surprised if, as he gets older and continues writing speeches of the sort he is composing now, he makes everyone who has ever attempted to compose a speech seem like a child in comparison. Even more so if such work no longer satisfies him and a higher, divine impulse leads him to more important things" (Plato 1995, 279a). Plato, writing this line at a time when Isocrates was no longer young but regarded by many as the preeminent teacher of the Western world, charges that the very heart of Isocratean education, rhetoric, is an unworthy aim.

And so the opening salvos were fired at the dawn of higher education. And we might be tempted to think that higher education today is still enmeshed in this debate between acquiring knowledge for its own sake or for the sake of civic life. Indeed, it seems like universities today are uneasily negotiating a tension between preparing graduates for contributions to the public good, or employment, on the one hand, and advancing an intellectual agenda centered on disinterested research, on the other. 
James R. Muir, in The Legacy of Isocrates and a Platonic Alternative, argues that, historically, there was no such tension. Isocrates won and Plato lost, and theories and practices of education (at all levels of schooling) are subordinate to or derived from politics, culture, or a doctrinal ideology. That is, regardless of whether one is teaching Marxism in the Soviet Union, or cultivating autonomy and tolerance in liberal democracies, all education is Isocratic in that "the goals and value of education are deduced from an axiomatic political doctrine which defines justice" (p.10).

Roughly the first half of Muir's book provides an overview of Isocrates' writings about education and his legacy in educational thought up to the Enlightenment. Muir has many secondary goals in this book, and one of them is to counter the tendency of philosophers of education to neglect (or misunderstand) the history of educational thought or, worse, deny that there was a continuous conversation about the nature, problems, and aims of education from antiquity to the Enlightenment (pp. 3-4, 19-20, 24). Muir reconstructs a continuous history of educational thought, from antiquity to today, rooted in Isocratic ideas about the relation of education to politics and culture. Muir's overview of the educational ideas of a range of different figures is admirably clear and only those rare scholars who seriously study the educational thought of antiquity, the Middle Ages, and the Renaissance will be familiar with each of the individuals and works he discusses. All other readers interested in the history of educational philosophy will find an engaging overview of Isocrates' legacy in educational philosophy over the next two millennia.

After establishing the importance of Isocrates' educational thought in the history of educational philosophy, Muir next argues that his legacy is pernicious. Though it may strike one as a surprising strategy to resurrect Isocrates merely to argue that he's mistaken about the nature of education, Muir treats Isocrates' legacy as an undiagnosed ailment; one must first identify the culprit before one can remedy the situation. The problem, as Muir sees it, is that the Isocratic principle of the relation of politics in education has compromised schooling today. Once Isocrates' influence is understood, educational theorists can revive the vanquished Parmenidean-Platonic understanding of education as autonomous: "its primary goal and value is preparation for freedom of thought about universal and trans-historical questions above all" (p. 203). Educational theorists have long seen education as the key to creating a more just society; citizenship for them is among the aims of education, if not the most important one. Muir argues, against Isocrates, that we must "reconsider the possibility that education is not a means to justice, but rather that the autonomy of education is a measure of the justice of any regime" (p.11; Muir's emphasis).

In an era in which infringement upon educators seems routine-we face demands from accreditors, from administrators, from the public, and from students-Muir's unapologetic argument for the autonomy of education is welcome. The contemporary predicament seems very much to call for such a response. But Muir's argument is simultaneously untimely in that today's educational theorists typically call for autonomy by appeal to the critical, socially engaged citizens that could emerge from their classes. Muir views such Isocratic justifications of education as no better than calls to indoctrinate students; either way, theorists are deducing the aims of education from preconceived political ideals.

But autonomous education for Muir does not imply that each teacher has free reign to teach what she pleases, as she pleases. On the contrary, Muir's proposal stipulates both pedagogy and curriculum. The curriculum is rooted in political theory, so students encounter and critique a diverse array of complex and sophisticated arguments that are the products of traditions: liberalism, Marxism and laissez faire capitalism, for example. With respect to pedagogy, Muir calls for teachers unwaveringly to prod their 
students to challenge the ideas they encounter, regardless of their own commitments, so that students transcend the arguments of their culture, and "begin to think freely and seek knowledge" (p. 235). Muir ultimately calls for a version of Great Books-type seminars. But his version would strenuously avoid the use texts and ideas to habituate and initiate students into a particular tradition or regime (as, he argues, E. D. Hirsch, Mortimer Adler, and Michael Oakeshott ultimately did; pp. 233-234).

Overall, Muir not only challenges contemporary assumptions about education, but also demonstrates the value of the history of educational philosophy; Muir's use of Isocrates illuminates assumptions about the relation of education to politics. In the spirit of Muir's call for robust debate of ideas, I will take up his claims about Isocrates' legacy and the failure of educational theorists to deal adequately with the history of educational philosophy.

Muir describes the Isocratic legacy as treating education as "derived from," "deduced from," or "subordinate to" political doctrine or culture. As I read, I wondered if this characterization of the relationship between education and politics/culture was too stark. Might this phrasing itself create a priority of politics/culture over education? Take, for example, Isocrates himself. Muir writes that Isocrates contended that "the normative intentions of education are deduced from the external and lexically prior political doctrine” (p. 40). Muir's analysis leaves education as a merely instrumental means of impacting politics. Might there be a way of reading Isocrates differently? What if one began with the assumption that Isocrates, rather than working out the implications of politics for education, worked out the implications of education for politics? That is, maybe Isocrates began by considering the aim of education, and concluded that the education ought to cultivate the kind of human who contributes to his community through politics. Isocrates was one of the greatest educational theorists and practitioners of the ancient world, a philosopher who, as Muir notes, revolutionized both curriculum and pedagogy. Politics might thus be understood as a place where the fruits of one's education are employed rather than the source of educational aims.

Even if Muir is right that Isocrates deduced the aims of education from politics-and, admittedly, Muir might be-I think that there are other educational thinkers about whom one might hesitate to ascribe the priority of politics over education. Consider Rousseau. I concede that Muir has a compelling case in that Rousseau's Considerations on the Government of Poland suggests that educational aims serve the seemingly primary political goal of social cohesion. ${ }^{1}$ Emile, on the other hand, begins by exploring education and only builds later, at the end of book V, to the political implications of the education he describes. One could make the case that, for Rousseau in Emile, politics is subordinated to education. Or, at least, one could conceivably argue that, for philosophers like Rousseau who thought so seriously about the relation of education and politics, education and politics were inextricably linked; to prioritize one would be to unravel a shroud, leaving nothing but heap of yarn.

In some cases, therefore, rather than insisting on educational aims being deduced from or subordinate to politics, Muir might have argued that those in the Isocratic tradition understood the aims of education to relate to politics. To say that education ought to relate to politics does not necessarily make it secondary; it merely allows philosophers to, rather than deducing educational aims from politics, work out conceptions of education and politics with reference to each other.

\footnotetext{
${ }^{1}$ However, even in that work, one could argue that Rousseau suggests that the best life is lived only as a citizen in a just regime, so political and educational goals are intermingled.
} 
Nevertheless, even if the Isocratic principle were described as I suggest, Muir's main argument still holds. Those in the Isocratic tradition did indeed think about education with a view to politics to which the Parmenidean-Platonic argument for the autonomy of education is a strong contrast. Muir's book is indeed valuable for illuminating this distinction. I turn next to another aspect of Muir's description of Isocrates' legacy in education: how educational philosophers have approached the history of educational philosophy.

As mentioned, Muir goes to lengths to show that "educationists"-whom he defines as scholars working in faculties of education-have failed to recognize that there is a history of education prior to the advent of state schooling in the 1700s (or they date the roots of educational philosophy even later, to the twentieth century). Muir introduces most historical figures by stating that educationists have "inadequately treated" (Augustine, p. 80), "neglected and misrepresented" (Martianus Capella, p. 93), or "ignored" (Alcuin and the whole of the Carolingian Renaissance, p. 97) them. The list could go on, and I could add Muir's charge that educationists ignore entire eras as well (e.g., the Middle Ages and twelfth century Renaissance, pp. $91 \& 103$ ).

I agree that philosophers of education have not focused much energy on the history of educational thought. Indeed, I'm on record in my belief that, as a result of this neglect, we have made some strange historical claims and unacceptable omissions (Mintz, 2018). Perhaps, however, as an "educationist" myself, I feel the need to defend us. Muir, it seems to me, unnecessarily overstates his case. For instance, Muir chides R. F. Dearden and R. S. Peters for simplistic readings of Rousseau. Muir writes, Rousseau "has been misrepresented by educationists" because of their "limited and partial familiarity with Rousseau's writings" (p. 151). Muir's argument would perhaps have been stronger had he outlined his criteria for determining whether educationists had dealt adequately with a given philosopher. Did Muir base his assessments on what was published by certain prominent scholars in the field? Or on what was published in certain journals? Or on what was presented at specific conferences? (Likewise, he makes some sweeping statements about the politically conservative thinkers that professors of education exclude from their courses. Is this verdict based on a review of syllabi? Is it deduced from the figures on which scholars of education typically publish?)

Contrary to Muir's claim that educationists misrepresent and are unfamiliar with Rousseau's work, we can claim as our own the Rousseau scholar who has arguably done the most important archival work on Rousseau's political thought in the twentieth century: Grace Roosevelt. ${ }^{2}$ Roosevelt was not only educated in a school of education but has spent her career as a teacher educator. Roosevelt is not alone. Tal Gilead-working in a school of education after earning a doctorate from a school of education-has been doing superb work on Rousseau and educational thought in the Enlightenment. And, particularly around the 250 th anniversary of the publication of Emile in 2012, a number of educationists published essays on Rousseau. The fate of Rousseau in education scholarship, I would suggest, is not nearly as bleak as Muir presents it.

\footnotetext{
${ }^{2}$ For those unfamiliar with Roosevelt's work: scholars had long pondered why Rousseau's State of War contained odd and sometimes incomprehensible arguments. Roosevelt travelled to Switzerland, examined the original manuscript, and proposed a reordering that became the basis for all subsequent scholarship on and publication of the work. Roosevelt describes her efforts in Reading Rousseau in the Nuclear Age (1990), wherein she also analyzes the relation of Rousseau's' educational and political thought. Chris Bertram, a former President of the Rousseau Association, listed Reading Roussean second on his list of the five best books on Rousseau of the twentieth century (Bertram, n.d.).
} 
Likewise, even on Isocrates, Muir overstates educational philosophers' poor record. He writes, "there has been little study of Isocrates' educational ideas in English, and none within Education Studies, despite the well-established and central role these ideas play in the history of educational thought and practice until the present day" (p. 17; my emphasis). "None" goes too far. Bruce Kimball placed an article on the legacies of Isocrates and Plato in Teachers College Record-one of the top general education journals (Kimball 1983)-and subsequently published an excellent book on the topic (Kimball, 1986). ${ }^{3}$ Like Roosevelt, Kimball is an "educationist," teaching in a school of education and having earned a doctorate in education. Muir's omission is not because of his ignorance of Kimball's work; Muir cites Kimball's two aforementioned works and two others. However, those citations appear in other contexts (e.g. pp. 94 \& 104) rather than amidst the discussion of the neglect of Isocrates by scholars of education where Kimball might have been recognized as a scholar of education who not only wrote about Isocrates but, like Muir, reckoned with his legacy in education.

One counter-example to Muir's claim about educationists' failure to deal with Isocrates is perhaps not worth dwelling on, but there are some other recent examples as well. Muir provides a list of almost thirty reference sources on educational philosophy dating from the early twentieth century that fail to discuss Isocrates. But Muir does not mention that the tide has turned recently. Curren (2007) included an excerpt from Isocrates in his anthology, and his anthology might be in wider use in philosophy of education classes than any other on Muir's list. D.C. Phillips' Encyclopedia of Educational Theory and Philosophy (2014) contains an entry on Isocrates of which Muir is well aware, as he wrote it himself. These efforts may be trickling down. I attended an educational philosophy conference recently and was surprised to hear an analytic philosopher who was giving a talk that had nothing to do with the history of educational philosophy (and who has published virtually nothing on the history of educational philosophy) make a castaway remark about the important ancients on education: Plato, Aristotle, and Isocrates. I write all this because Muir might have framed his narrative otherwise: After a century of neglect, Isocrates is at last beginning to take his rightful place in the history of educational thought.

Muir himself deserves much credit for this change of events, publishing several articles on Isocrates and now this book. It does not bode well for the study of the history of educational philosophy if it takes this kind of Herculean effort to bring a single historically important educational philosopher to the attention of the field, but it does reveal that progress can be, and has been, made. It is not often that a field makes new room in its canon for important ideas and figures. Muir should be commended for his role in bringing this about.

\section{References}

Bertram, C. (no date). The best books on Jean-Jacques Rousseau (N. Warburton, Interviewer). Five books. Retrieved from: https://fivebooks.com/best-books/rousseau-christopher-bertram/ Curren, R. (2007) Philosophy of Education: An anthology. Malden: Blackwell Publishing. Isocrates. 2000. Isocrates I. Trans. David C. Mirhady and Yun Lee Too. Austin: University of Texas Press.

\footnotetext{
${ }^{3}$ Kimball credits much more influence to the philosophers in the history of liberal education than does Muir.
} 
Kimball, B. A. (1983). Founders of" liberal education": The case for Roman orators against Socratic philosophers. Teachers College Record, 85(2), 225-49.

Kimball, B.A. (1986). Orators \& philosophers: A history of the idea of liberal education. New York: Teachers College Press.

Mintz, A.I. (2018). The use and abuse of the history of educational philosophy. Philosophy of Education Yearbook 2016, ed. Natasha Levinson (Urbana, IL: Philosophy of Education Society), 483-492.

Phillips, D.C. (2014). Encyclopedia of educational theory and philosophy. Los Angeles, California: SAGE reference.

Plato. 1995. Phaedrus. Trans. Alexander Nehamas and Paul Woodruff. Indianapolis: Hackett Publishing Company.

Roosevelt, G.G. (1990). Reading Rousseau in the nuclear age. Philadelphia: Temple University Press.

\section{About the Author}

Avi I. Mintz is the author of Plato: Images, Aims and Practices of Education (Springer, 2018) and has published several articles on the history of educational thought. 